\title{
International Committee on Systematic Bacteriology \\ Subcommittee on the Taxonomy of the Actinomycetales
}

Minutes of Meetings, 5 and 6 October 1976

Forum Hotel, Warsaw, Poland

Minute 1. Attendance. Members present were E. Küster (Chairman), T. Arai, G. Bradley, W. Kurylowicz, R. Locci, Y. Okami, H. Prauser, T. Preobrazenskaya, and S. Williams. Apologies for absence were received from J. Slack, G. De Vries, T. Pridham, and L. Kalakoutskii. Nonmembers present (5 Oct.) were G. Gause, M. Goodfellow, E. Golovlev, Y. Konev, H. Kutzner, J. Lacey, M. Magnusson, I. Szabo, and K. Schaal.

Minute 2. Chairman's report. The Chairman (E. Küster) referred members to his report of March 1976 which had been circulated.

Minute 3. Genera for which Subcommittee is responsible. After some discussion, it was agreed that a list of genera proposed by Dr. Prauser would serve as the basis for this. Subgroup chairmen should indicate genera for which they were responsible.

Minute 4. ICSB request for approved genera and species. It was agreed that the Chairman should contact Dr. Skerman to discover what information had already been collected from individual experts and what was still required. Authors of genera or other suitable experts should then be asked to provide lists of approved species. It was felt that it would be useful to present lists for comment before they were finalised (e.g., in "The Biology of the Actinomycetes"). Comments should be returned to authors of the species lists.

Minute 5. Reorganisation of subgroups. The new
Subcommittee on Nocardia and Allied Taxa had not yet been set up but it was hoped that this would soon occur. Dr. J. Slack has retired from the Subcommittee and his chairmanship of the micro-aerophiles subgroup. Members of this subgroup will be contacted for their views on a successor to Dr. Slack. A Streptomyces subgroup will be set up and Dr. T. Pridham will be asked to be chairman.

Minute 6. Minimum standard methods for characterization of taxa. After some discussion it was decided that it would not be feasible for the committee to lay down standard methods for all taxa in the next 4 years. Priority should be given to formulating lists of approved taxa (see minute 4). It may be possible to initiate collection of information on minimum standard methods for selected genera containing few species. Workers responsible for Bergey descriptions of such genera could be contacted to provide information for discussion at the next Subcommittee meeting.

Minute 7. Retirement of Secretary. Dr. T. Preobrazenskaya asked to be relieved as secretary of the Subcommittee. It was agreed that S. Williams would act as secretary for the next two years.

Minute 8. Next meeting. The next meeting will be held in Munich in 1978.

E. Küster, Chairman

S. T. Williams, Secretary 